\title{
Cotton/polyester and cotton/nylon warp knitted terry cloth: Why minority fibre content is important
}

\author{
Adine Gericke, Laetitia Viljoen, Riette de Bruin
}

\begin{abstract}
Opsomming
Suid Afrikaanse wetgewing insake die etikettering van tekstiel produkte laat ' $n$ speling toe wat betref die aanduiding van veselinhoud op etikette. Die vraag wat in hierdie studie gevra word, is of ' $n$ speling toegelaat behoort te word, veral in gevalle van mengselstowwe soos katoen/poliëster en katoen/ nylon skeringgebreide terriestowwe. Die effek van industriële wasprosedures op die duursaamheid van katoen skeringgebreide terriestof met ' $n$ sintetiese basisstruktuur van óf katoen óf poliëster is ondersoek om te bepaal of die relatief klein komponent sintetiese garing ' $n$ beduidende rol speel in die behoud van die duursaamheid van die tekstielstowwe. Die breeksterkte van katoen-nylon en katoen-poliëster terriestof handdoekmonsters nadat dit aan onderskeidelik 50 industriële wassiklusse en 50 industriële was-en drogingsiklusse onderwerp was, is vergelyk. Die verskil in die breeksterkte van die monsters wat slegs gewas is, was nie betekenisvol nie. In die geval van monsters wat gewas én getuimeldroog is, was die breeksterkte van die katoen-nylon monsters egter betekenisvol laer as dié van die katoen-poliëster monsters. Dit het gelei tot die gevolgtrekking dat industriële versorgingsprosedures, en veral tuimeldroging, ' $n$ meer nadelige effek op die duursaamheid van ' $n$ terriestof met ' $n$ nyIon basisstruktuur as op een met ' $n$ poliëster basisstruktuur het. Dit was ook duidelik dat die poliësterkomponent ' $n$ belangrike rol gespeel het in die behoud van die breeksterkte van die monsters. Die rol van die klein komponent sintetiese garings in die basisstruktuur van hierdie stowwe moet dus nie onderskat word nie en in sulke gevalle behoort die kleiner veselinhoud ook spesifiek op die etiket aangedui te word. Onnodige foute, soos byvoorbeeld die volg van verkeerde versorgingsprosedures as gevolg van oningeligheid, sou sodoende voorkom kan word.
\end{abstract}

\section{- Ms A Gericke}

Department of Chemistry and Polymer Science University of Stellenbosch

\section{- Ms L Viljoen}

Former Department of Consumer Science University of Stellenbosch

\section{- Ms $R$ de Bruin}

Master's Student: Former Department of Consumer Science

University of Stellenbosch

\section{INTRODUCTION}

In terms of Notice 657 of 2005 in the Government Gazette, no textile product may be sold in the Republic of South Africa, irrespective of whether such goods were produced in the country or elsewhere, unless it conforms to the South African National Standards for fibre content and care labelling of textiles and textile products (Government Gazette, 2005:3). This standard, revised in June 2007, states clearly how fibre content should be indicated and what the tolerances are (South African National Standards, 2007:4,5). This gives rise to the following question, namely: Should tolerances be permitted at all; in other words, should a label be allowed to indicate "all cotton" if there are other fibres present in the fabric construction (albeit in a very small percentage)? This in turn gives rise to a further question, namely: How important is it that a minority fibre content be identified on the label?

The lifespan of a textile product is directly related to the number of wash cycles it can endure. Should one component of a textile structure fail prematurely it will lead to degradation of the entire product, rendering it unfit for further use. Durability during use is therefore dependent on the compatibility of care procedures with fabric construction and fibre content. In the manufacturing of the textile products that today's market demands, new construction methods and fibre combinations are often implemented. One yarn of different fibre content from the rest, comprising a very small percentage of the whole, might be added for an aesthetic or functional purpose and, although hardly noticeable, it could comprise an integral part of the construction. Should it be damaged in any way by, for example, wrong choice of care procedures, possibly due to the consumer being uninformed or misinformed, it can lead to disintegration of the entire construction. This is one of the reasons why accurate fibre content and care labelling are of utmost importance.

Warp knitted terry cloth is manufactured on a Raschel warp knitting machine, using three sets of warp yarns (Hatch, 1993:358; Kadolph \& Langford, 2002:235; Miller, 1992:108). The ground structure of pillar stitches, similar to chain stitching, is formed by the first set of warp yarns. Pillar stitches of adjacent courses are not connected. A second set of warp yarns are looped into this base structure in the weft direction each set connecting four adjacent courses of pillar stitches - adding stability and strength in the weft direction to the structure. The third set of yarns, referred to as the pile yarns, form the pile loops. When warp 


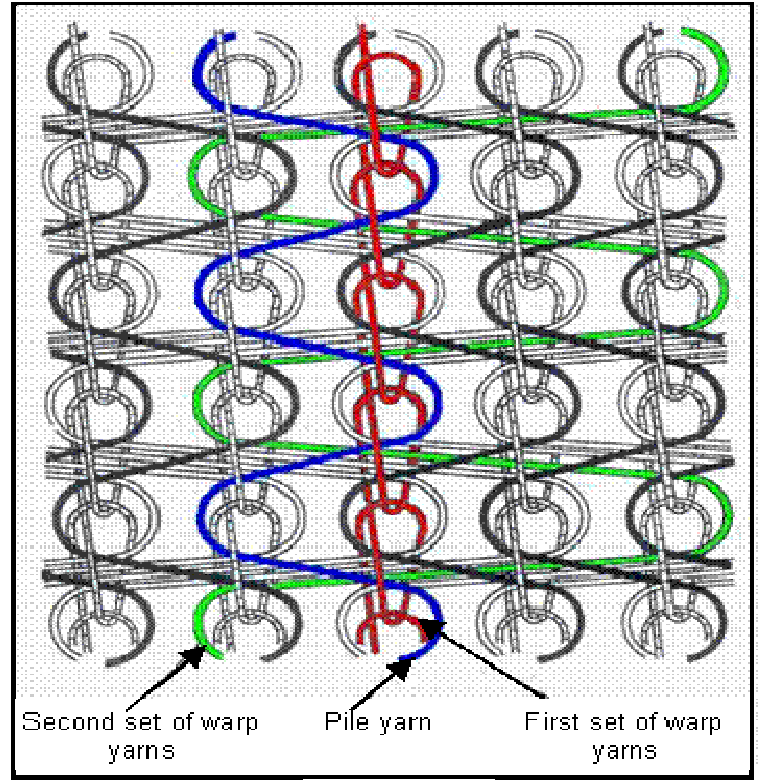

FIGURE 1: ILLUSTRATION OF WARP KNITTED TERRY CLOTH FABRIC STRUCTURE (Innovative technology makes its mark, 2004:1)

knitting terry cloth, one needle-bar is replaced with a point or pin-bar, around which the pile yarns are overlapped when the pile loops are formed (Miller, 1992:109; Spencer, 1983:326). An illustration of the structure is shown in Figure 1. (In this illustration the length of the pile yarns is not depicted to scale).

This production method is generally more economical than the traditional slack-tension weave method because of the high production speed (Anand \& Smith, 1994:68) and has the added advantage of enhanced durability because of the synthetic component that can be incorporated into the structure (Kadolph \& Langford, 2002:41). In practice, the ground yarns of warp knitted terry cloth fabrics often differ in composition to the yarns of the pile (Miller, 1992:109, Wooten, 1979). Synthetic fibres like nylon and polyester are mostly used in the ground structure - adding stability and strength (Hegde et al, 2004, Wiska, 2003). As inferred from the structure of the warp knitted terry cloth (see Figure 1), the synthetic component plays a vital role in the durability of the towels, especially where breaking strength in the warp direction is concerned.

Cotton is generally used as pile yarn in warp knitted terry cloth because of its excellent absorbency. The second set of warp yarns is often also cotton, used to maintain the high absorbency, but also because cotton is reasonably priced and actually increases in strength when wet (Kadolph \& Langford, 2002:41; Miller, 1992:109). Such fabrics can be described as cotton-polyester or cotton-nylon mixtures.

South African National Standard 10235 (2007:4-7) specifies methods of designating the fibre content of textiles and textile products and for applying this information to made-up products, piece goods and yarns. For a textile product to be classified as a single-fibre type it must be so composed as to contain not more than two percent of other fibres classed as "inadvertent impurities", or five percent of other fibres in the case of carded fibres or seven percent of other fibres with a decorative function. In these cases fibre content can be indicated as "all cotton", "pure cotton" or even " $100 \%$ cotton". In practical terms it is therefore possible that a fabric containing $96 \%$ cotton and $4 \%$ nylon or polyester can be labelled as "all cotton".

A product composed of two or more fibre types is classified as a "blended fibre type product" (South African National Standard, 2007:5). A blend is defined as an intimate mixture of fibres of different generic type, composition, length, diameter or colour spun together in a yarn (Hatch, 1993:295; Kadolph \& Langford, 2002:151). In this case the label should indicate the name of the main fibre type and the percentage that it accounts for, or the names of all fibre types as well as their respective percentages, in descending order, or just a listing, in descending order of dominance (by mass), the generic name of each fibre type.

The standard also allows for blends in cases where a product may contain two or more fibre types that together accounts for ten percent or less of the total mass of the product, in which case these fibres may be collectively marked as "other fibres", followed by their total combined percentage. It is not compulsory to indicate their generic names (South African $\mathrm{Na}$ tional Standard 2007:5). A consumer may thus be confronted with a label stating that the product contains $85 \%$ cotton, for example, but what the rest is may remain unknown to the consumer.

The standard does not refer directly to fabrics where certain yarns in the weft or warp differ from the rest in fibre content, such as in the case of warp knitted terry cloth. These fabrics are usually defined as "mixtures" and are composed of yarns differing from each other in fibre composition (Hatch, 1993:298; Kadolph \& Langford, 2002:150). In this case the synthetic fibre content, because of the low weight of the filament yarns, can comprise a very low percentage of the total fibre content. One of the questions addressed in this study is whether the role that this small percentage plays in maintaining the durability of a fabric is significant.

In the hospitality industry durability is of utmost importance. Towels, for example, can be subjected to washing on a daily basis and, although industrial laundering procedures are often more severe than household procedures, this is considered as "normal" in the hospitality industry. Premature failure due to the inability of a product to withstand laundering procedures can lead to huge losses or claims against suppliers. It is therefore of utmost importance that the care procedures followed by industrial launderers are compatible with the fibre content and fabric construction of the laundered items (Hatch, 1993:206; Merkel, 1991:110).

Industrial launderers generally make use of continuous batch washing machines, referred to as continuous batch tunnel washers (CBTW) (Fabric Care Re- 
search Association, 1993:4; Jakobi \& Löhr, 1987:221). These machines are designed to remove soiling, contamination and micro-organisms from large quantities of dirty linen. The process usually entails a pre-wash, main wash and rinse, followed by tumble-drying. Preweighed loads of laundry pass through a number of compartments (typically ten to twelve) in which they are pre-washed, washed and rinsed. A CBTW machine usually works with an internal counter-flow current system in which the wash load moves forward in the machine (from one compartment to the next) while the water flows in the opposite direction (Barrie, 1994; Fabric Care Research Association, 1993:4, 9; Jakobi \& Löhr, 1987:221).

Chemical additives are added automatically to the appropriate compartments and steam can be injected into the main wash compartments to achieve the required high temperatures. Stains and soil are removed by a combination of mechanical action, time and temperature control, detergent action and de-staining agents, which can include bleaches. For thermal disinfection the achievement and maintenance of the required temperature is critical. The most important specific factors that influence effective cleaning and also the retention of the durability of the textiles being laundered are temperature, wash time, level of wash liquid (dip), mechanical action during washing, additives, the tumble-drying process, etc. (Fabric Care Research Association, 1993:3,9). Of these, the temperature, additives and tumble-drying are of particular relevance to this study.

Temperature control during each phase of the laundering process is necessary because, on the one hand, temperature has a direct influence on effective soil and stain removal, and on the other, certain fabrics are sensitive to prolonged exposure to high temperatures. Temperature control is also important when using hypochlorite bleaching agents, as bleaching at too high a temperature can damage certain fibres. In the hospitality and medical industries temperature plays an important role in the disinfection process; it is important that the critical temperature is reached to ensure effective disinfection (Fabric Care Research Association, 1993:3, 9). According to Steyn (1994:216), a washing temperature of higher than $54^{\circ} \mathrm{C}$ is necessary to ensure effective elimination of micro-organisms in household laundering. In industrial laundries temperatures of at least $71^{\circ} \mathrm{C}$ for three minutes or $65^{\circ} \mathrm{C}$ for ten minutes are recommended as safe time/temperature combinations for thermal disinfection. Additional time should be allowed for adequate penetration in large laundry loads. It is usually preferable to employ a higher temperature range to ensure thorough disinfection, and temperatures up to $85^{\circ} \mathrm{C}$ are often reached within certain areas in the machine (Fabric Care Research Association, 1993:9).

Cotton is not thermoplastic and will not melt in the presence of heat (Tortora, 1992:131). Normal exposure to elevated temperatures, as found in routine care procedures, will not degrade cotton. White fabrics can be washed in hot water $\left(95^{\circ} \mathrm{C}\right)$, but temperatures higher than $60^{\circ} \mathrm{C}$ are not recommended for col- oured fabrics (Joseph, 1988:67). Temperatures in the tumble-dryer should not exceed $93^{\circ} \mathrm{C}$ in order to prevent the acceleration of fibre degradation (Trotman, 1984:44)

The melting point of nylon varies between $215^{\circ} \mathrm{C}$ and $260^{\circ} \mathrm{C}$, depending on the type of nylon (Kadolph \& Langford, 2002:102). The swelling of the nylon fibres in water, together with their thermoplastic nature and the tendency of the fibres to weaken slightly when wet, limits the vigorousness of the laundering conditions that nylon can withstand, and therefore moderate washing and drying temperatures are recommended (Hatch, 1993:206; Kadolph \& Langford, 2002:102; Tortora, 1992:131).

Polyester has the highest thermal resistance of all the synthetic fibres; it has a melting point of between $250^{\circ} \mathrm{C}$ and $288^{\circ} \mathrm{C}$. Of considerable importance are the facts that the polyester fibres do not swell in water and that their physical properties are not significantly altered by the temperatures used during the care procedures. Polyester fabrics can thus be submitted to fairly rigorous laundering conditions (Hatch, 1993:219; Joseph, 1988:106; Tortora, 1992:195; Wingate \& Mohler, 1984:371).

Additives used during laundering can include detergents, alkalis and bleaching agents. Synthetic detergents are usually alkaline and are used to remove or suspend soil, reduce the effect of hard water or reduce the surface tension of water with the purpose of enhancing soil removal. A detergent solution with a $\mathrm{pH}$ value higher than 10 enhances the effectiveness of the wash process (Fabric Care Research Association, 1993:16)

An alkaline medium will not damage cellulose fibres even at high temperatures, so all detergents on the market can be used to wash cotton fabrics (Hatch, 1993:168; Joseph, 1988:67; Wingate \& Mohler, 1984:248). Both nylon and polyester, as used in the ground structure of the terry cloth fabrics, have excellent resistance to alkaline wash mediums. Polyester can be damaged by strong alkali but has good resistance to weak alkali, such as found in detergents (Hatch, 1993:207,218; Joseph, 1988:68,106; Kadolph \& Langford, 2002:100,107; Tortora, 1992:183,195).

During the rinse phase the remaining detergent and suspended soil is removed through dilution. A weak acid solution can be added to neutralise the alkalinity of the wash liquid. Cellulose fibres, such as cotton, are damaged by strong acids, but even weak acids can degrade the fibres if not removed properly during rinsing (Joseph, 1988:67; Wingate \& Mohler, 1984:231). Polyester has excellent resistance to acids, but nylon is sensitive to hydrochloric acid and can be damaged if exposed to sulphuric acid. The effect of extended exposure to weak acids, especially in the wet state, is questionable (Kadolph \& Langford, 2002:101; Mclntyre, 2000:71; Tortora, 1992:183).

Bleaches are generally used during laundering procedures to remove stains. The choice of a suitable 
bleaching agent is dependent on fibre type. The temperature of the washing liquid and the concentration of the bleaching agent should be carefully controlled, as degradation takes place more easily at higher temperatures and concentrations. Cotton is highly sensitive to chlorine bleach and can be degraded by extensive use thereof, whereas polyester is unaffected. Chlorine bleach is also known to cause damage to and discolouration of nylon fabrics (Hatch, 1993:168, 207, 218; Kadolph \& Langford, 2002:39, 101, 107; Tortora, 1992:123, 195).

Tumble-drying is the standard method of drying laundry during industrial laundering procedures. The size of the load in the dryer, the mechanical action, and the time and temperature of drying have an effect on the amount of abrasion, and subsequently degradation that textile fabrics are exposed to (Kadolph \& Langford, 2002:352). Deans (2001) reports that tumbledrying is not a homogenous process. Both the distribution of textile items in the drum and the variation in the temperatures of the air, sides of the drum and textiles being dried are dependent on the textile fabric type(s), moisture content and packing density of the load. The nature of the textiles in the load influences the amount of moisture that migrates to the surface as well as the cohesion of items in the bundle. Although Hatch (1993:219) claims that polyester will maintain between $70 \%$ and $80 \%$ of its tenacity upon prolonged exposure to temperatures exceeding $150{ }^{\circ} \mathrm{C}$, it is not recommended that fabrics with a synthetic fibre content (especially nylon) should be exposed to conditions such as those occurring during tumble-drying for extended periods, as this could lead to degradation because of the high temperatures that can develop in the tumble-dryer (Kadolph \& Langford, 2002:93, 100, 107).

Hence the question has arisen as to whether there is a difference in the effect of industrial laundering procedures on warp knitted terry cloth towels with nylon yarns in the ground structure compared to a similar fabric with polyester in the ground structure.

\section{PURPOSE OF THE STUDY}

The main purpose of the study was to compare the durability of cotton warp-knitted terrycloth with a nylon ground structure to cotton warp-knitted terrycloth with a polyester ground structure after exposure to industrial laundering procedures and to determine whether the relatively small percentages of nylon or polyester play a significant role in maintaining the durability of the fabrics.

In order to determine this, cotton/nylon and cotton/ polyester terrycloth samples were first analysed to determine their structural properties and then compared with regards to the durability of the respective fabrics after exposure to industrial washing as well as industrial washing and tumble-drying

\section{RESEARCH PROCEDURE}

In order to describe the test samples and determine the similarity (and therefore comparability) of the cotton/nylon and cotton/polyester terry cloth, the fibre composition of the cotton/nylon and cotton/polyester textile samples was determined according to the ISO 1833-standard test method (Test 10). The structural characteristics were compared by analysing the knitted structures under a microscope. The average stitch density of the textile samples was determined according to SABS method 1120 . The average weight of the unwashed cotton/nylon and cotton/polyester terry cloth samples was determined according to SABS method 79.

\section{Description of test samples}

Fibre composition The average nylon content of the cotton/nylon terry cloth samples was $4,40 \%$. The cotton/polyester terry cloth samples had an average polyester content of $4,43 \%$. The difference in synthetic content of the two groups of samples was small enough for the synthetic components to be considered as being similar.

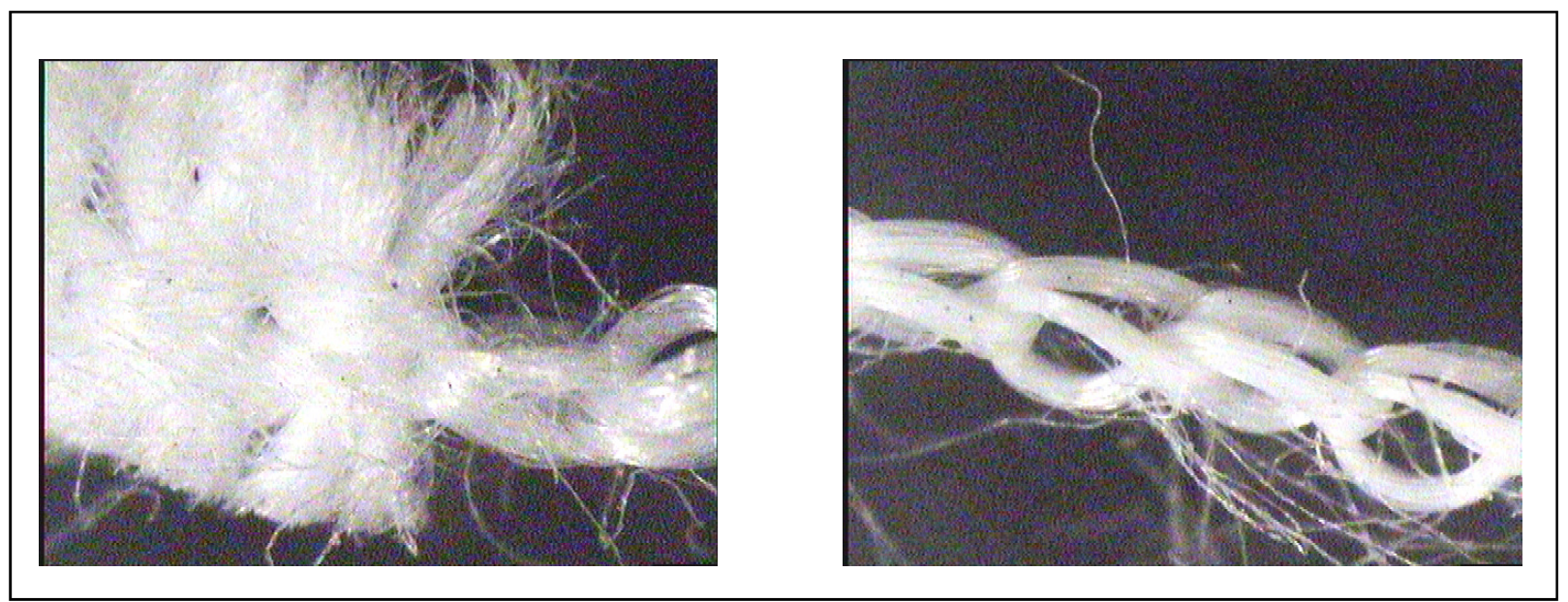

FIGURE 2: MICROSCOPIC IMAGES OF WARP KNITTED TERRY CLOTH FABRIC (100x ENLARGED) SHOWING A STRIP OF CHAIN STITCHES (FORMING THE CORE OF THE WARP KNITTED STRUCTURE) WITH THE REST OF THE WARP YARNS CUT AND UNRAVELLED 
Structural characteristics The knitted structure of both groups of terry cloth samples was identified as warp knitted terry cloth mixture fabrics in which three sets of warp yarns were used, similar to those shown in Figure 1. From an optical microscopy analysis (Figure 2) it was clear that the pillar stitches that formed the ground structure of the fabric were filament (synthetic) yarns. The other two sets of yarns, namely the second set of warp yarns and the pile threads, were both cotton.

In terms of the stitch density, the cotton/nylon terry cloth samples had an average of 48,2 whales and 65,8 courses per $10 \mathrm{~cm}$, while the cotton/polyester terry cloth samples had an average number of 46,3 whales and 62,7 courses per $10 \mathrm{~cm}$. The cotton/nylon terry cloth samples therefore had a slightly higher knit density than the cotton/polyester terry cloth samples. The average mass of the untreated cotton/nylon and cotton/polyester terry cloth samples was $560,1 \mathrm{~g} / \mathrm{m}^{2}$ and $522,2 \mathrm{~g} / \mathrm{m}^{2}$ respectively. The average tensile strength of cotton/nylon terrycloth samples before treatment was $296,24 \mathrm{~N}$ and that of cotton/polyester was 297,84 N. A variance analysis (ANOVA) was done on the above-mentioned results to statistically determine the significance of the differences, after which the cotton/nylon and cotton/polyester warpknitted terrycloth samples were considered comparable in terms of structural properties for the purpose of this study.

Chemical damage To first determine possible existing chemical damage to the cotton fibres as a result of the manufacturing process, cuprammonium fluidity tests were carried out on cotton fibres from the unwashed cotton/nylon and cotton/polyester terry cloth samples. The fluidity values of both textile samples were $<1$ and the degrees of polymerisation (DP values) were $>3000$, which showed that no chemical damage had taken place at that stage (CSIR Manufacturing and Materials Technology Centre for Fibres, Textiles and Clothing, 2004:2).

\section{Durability of cotton/nylon and cotton/polyester warp knitted terry cloth samples after industrial washing and wash/tumble-drying}

Samples were exposed to laundering procedures representative of those currently used in industrial laundries, which included washing in a continuous batch washing machine and tumble-drying. Test samples were washed and tumble-dried together with other laundry and exposed to 50 wash and 50 wash/tumbledry cycles.

Wash bundles, weighing $35 \mathrm{~kg}$ per bundle, included only towels. Each bundle of washing was weighed in advance to ensure the correct loading level and the corresponding concentration of wash additives during the washing process. Wash bundles were loaded in compartments on a conveyor belt that fed into the washing machine. The continuous batch washing machine used in this study has 12 different compartments into which washing additives are added in different stages. In the first two compartments (pre-wash area) of the machine the temperature does not exceed $30^{\circ} \mathrm{C}$. In the next two compartments, still in the prewash area, a temperature of $78^{\circ} \mathrm{C}$ is reached. In the main wash area, consisting of compartments five to eight, the $78^{\circ} \mathrm{C}$ temperature is maintained. In the rinse area, in compartments nine to ten, the temperature gradually decreases to $55^{\circ} \mathrm{C}$ and $45^{\circ} \mathrm{C}$ respectively. In the last two compartments there are again no specified temperatures to be reached. The procedure is computer-controlled to ensure adherence to specified processes and temperatures.

After washing, the excess water is pressed from the laundry before it is transported via a conveyor belt to a tumbler (not a tumble-dryer) to loosen the washing items from each other before loading into the tumbledryer. The samples that were only to be washed were loaded back into the washing machine directly after tumbling, omitting the tumble-drying process. To facilitate sorting and prevent mistakes the samples were marked with brightly coloured ribbons - one colour for those only to be washed and another for those to be tumble-dried. The laundering procedures were conducted under supervision of the researcher to ensure strict control during the procedures.

The industrial tumble-dryers were set to reach a maximum temperature of $120^{\circ} \mathrm{C}$. During the study temperature strips were used to measure the actual temperatures inside the tumble-dryers. Temperatures of between $104^{\circ} \mathrm{C}$ and $110^{\circ} \mathrm{C}$ were measured. A load of towels took between 30 and 45 minutes to dry, depending on the size of the load.

In order to compare the durability of cotton/nylon and cotton/polyester warp knitted terry cloth, the tensile strength of the test samples in the warp direction was determined after exposure to 50 wash and 50 wash/ tumble-dry cycles according to the SABS method ISO 13934-1 on an Instron Universal Testing Machine. Change in tensile behaviour of fibre appears to be the almost universal way to recognize deterioration (Slater, 1991). Ten test samples per terry cloth sample exposed to a specific treatment combination were tested to ensure the calculation of a representative average. Prior to testing, all test samples were conditioned according to standard procedures for 24 hours under controlled atmospheric conditions $\left(20 \pm 2{ }^{\circ} \mathrm{C}\right.$ and $65 \pm 2 \%$ relative humidity).

The tensile strength tests were only carried out in the warp direction because the nylon or polyester ground structure (pillar stitches) runs only in this direction. Adjacent rows of pillar stitches are not directly intertwined, but bound to each other by means of a second set of cotton warp yarns (see Figure 1). Since the purpose of this study was the comparison of the nylon and polyester components of the warp knitted terry cloth, it was not relevant to compare the tensile strength of the two sets of samples in the weft direction. The dimensional stability of the test samples was determined according to SABS method 960 and adjustments made accordingly to the tensile strength results of the washed samples. 
TABLE 1: VARIANCE ANALYSIS OF AVERAGE TENSILE STRENGTH RESULTS

\begin{tabular}{|l|c|c|c|c|c|c|}
\hline Sample description & $\begin{array}{c}\text { Source of } \\
\text { variance }\end{array}$ & $\begin{array}{c}\text { Sum of } \\
\text { square }\end{array}$ & $\begin{array}{c}\text { Degrees of } \\
\text { freedom }\end{array}$ & $\begin{array}{c}\text { Mean } \\
\text { square }\end{array}$ & F-ratio & p-value \\
\hline $\begin{array}{l}\text { Terry cloth samples } \\
\text { washed } 50 \text { times }\end{array}$ & Fibre content & 2538 & 1 & 2538 & 5,907 & 0,0181 \\
\cline { 2 - 7 } & Fault & 24922 & 58 & 430 & & \\
\hline $\begin{array}{l}\text { Terry cloth samples } \\
\text { washed and tumble } \\
\text { dried } 50 \text { times }\end{array}$ & Fibre content & 42756 & 1 & 42756 & 62,537 & $p<0,001$ \\
\cline { 2 - 7 } & Fault & 39655 & 58 & 684 & & \\
\hline
\end{tabular}

Fluidity tests were carried out on cotton fibres from the laundered cotton/nylon and cotton/polyester terry cloth samples to determine if there was any chemical damage to the cotton fibre structure.

\section{Data analysis}

To compare the results of the tensile strength tests, a two-directional cross-classification variance analysis (ANOVA) was used with fibre content and laundering procedure as factors. The main effects were directly interpreted if the interaction effects were not significant; otherwise various one-directional ANOVAs were done at each of the levels of industrial laundering procedures to determine if the tensile strengths differed significantly. A Bonferroni multiple comparison procedure was used to determine where the differences between levels of the main effects were. Throughout this study a $5 \%$ significance level was used. The fibre content included cotton/nylon and cotton/polyester for the purposes of the analyses. The care procedures included unwashed, washed, and washed/tumbledried.

\section{RESULTS AND DISCUSSION}

The main purpose of this study was to compare the durability of cotton/nylon and cotton/polyester warp knitted terry cloth fabrics exposed to industrial laundering procedures. The tensile strength results of samples that were washed 50 times or washed and tumble-dried 50 times were compared to the tensile strength of the unwashed samples, as any change in tensile strength serves as a direct indication of a change in textile structure, implicating a change in durability (Merkel, 1991:110).

Of the samples that were washed for only 50 wash cycles, the cotton/nylon terry cloth samples had an average tensile strength of $260,82 \mathrm{~N}$, while that of the cotton/polyester terry cloth samples was $273,82 \mathrm{~N}$. The average tensile strength of the cotton/nylon terry cloth samples exposed to 50 wash/tumble-dry cycles was $222,04 \mathrm{~N}$ and that of the cotton/polyester samples was $275,43 \mathrm{~N}$. These results are graphically illustrated in Figure 3.

A two-directional ANOVA was done on tensile strength against laundering procedures. The interaction was significant $(p<0,01)$; and thus one- directional ANOVAs are given for each level of laundering in Table 1.

The tensile strengths of both cotton/nylon and cotton/ polyester warp knitted terry cloth samples that were washed 50 times were lower than those of the untreated samples, but only the decrease in average tensile strength of the cotton/nylon terry cloth samples was significant $(p<0,05)$. Statistical analyses confirmed that there was no significant difference $(p>0,05)$ between the average tensile strength of cotton/nylon and cotton/polyester terry cloth samples that were exposed to 50 washing cycles. In the case of cotton/nylon fabric this greater decrease in tensile strength can probably be attributed to the fact that nylon fibres swell and weaken slightly in water as the hydrogen bonds in the amorphous areas of the fibre break when water molecules are absorbed. The thermoplastic nature of nylon also causes it to deteriorate during harsh laundering procedures at high tempera-

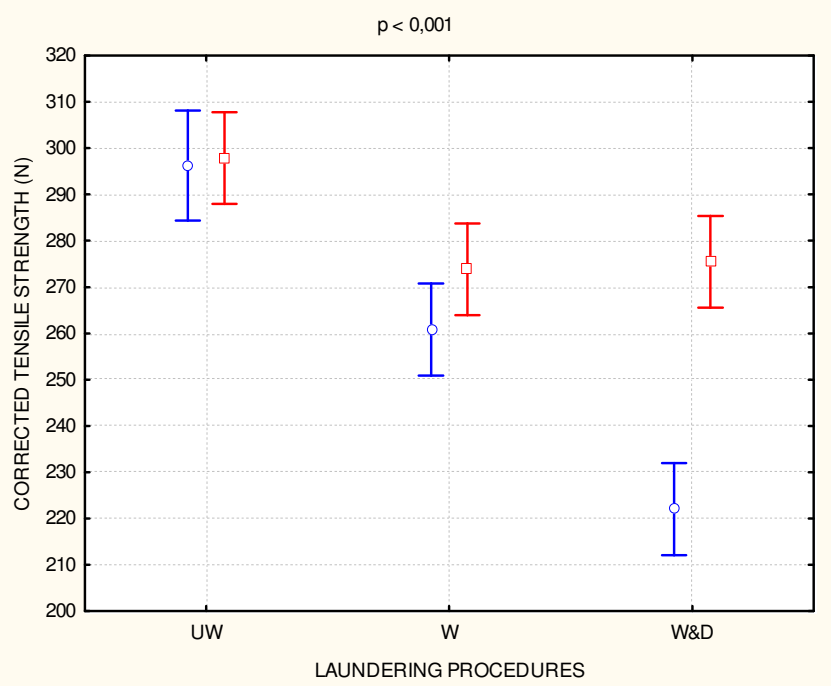

$0=$ cotton/polyester $\mathrm{m}=$ cotton/nylon

UW = unwashed $\mathrm{W}=$ washed $\mathrm{W} \& \mathrm{D}=$ washed and tumble dried

\section{FIGURE 3: $\quad$ COMPARISON OF THE TENSILE STRENGTHS OF UNWASHED (UW), WASHED (W) AS WELL AS WASHED AND TUMBLE DRIED (W\&D) COTTON/NYLON AND COTTON/POLYESTER WARP KNITTED TERRY CLOTH SAMPLES}


tures (Hatch, 1993:206). A temperature of $78^{\circ} \mathrm{C}$ is reached during the washing process, which is much higher than the recommended temperature as presented in literature (Hatch, 1993:206; Kadolph \& Langford, 2002:102; Tortora, 1992:131). The temperature reached during tumble-drying was also as high as $110{ }^{\circ} \mathrm{C}$, and in this case the exposure was even longer than in the washing process.

The reason for the decrease in the tensile strength of the cotton/polyester terry cloth samples can not be attributed to the polyester component, as there is no significant difference between the wet and dry strength of polyester fibres. The abrasion resistance and strength of polyester fibres are not influenced by the presence of water, and are expected to remain stable after repeated washes (Joseph, 1988:67; Kadolph \& Langford, 2002:102; Mason, 1999; Wingate \& Mohler, 1984:360). It is highly improbable that the alkalinity of the detergents caused the decrease in tensile strength as polyester fibres are only degraded by strong alkaline (Hatch, 1993:207, 218; Joseph, 1988:68,106; Kadolph \& Langford, 2002:100, 107; Tortora, 1992:183, 195).

The tensile strengths of the cotton/polyester terry cloth samples that were washed 50 times and those that were washed and tumble-dried 50 times did not differ significantly $(p>0,05)$. The tensile strength of the cotton/nylon terry cloth samples did, however, decrease significantly. This decrease in tensile strength was highly significant $(p<0,001)$. There was also a highly significant difference $(p<0,001)$ between the tensile strengths of the cotton/nylon and the cotton/polyester terry cloth samples after the 50 wash/tumble-dry cycles.

In terms of the results of the cuprammonium fluidity tests, the fluidity value of the cotton in the cotton/nylon terry cloth samples changed from $<1$ to 5,46 , and the DP-value from $>3000$ to 1848 after being washed 50 times and tumble-dried. According to the laboratory report these values are comparable to normal damage during washing and bleaching during manufacturing. In contrast to this, the fluidity value of the cotton in the cotton/polyester terry cloth samples changed from $<1$ to 19,60 and the DP-value from $>3000$ to 854 after being washed 50 times and tumble-dried. These values are comparable to those of strenuously bleached cotton, which points to a definite chemical damage (CSIR Manufacturing and Materials Technology Centre for Fibres, Textiles and Clothing, 2004:2). The difference in the extent of damage of the cotton in the cotton/nylon and cotton/polyester terry cloth samples is difficult to explain, as they were both exposed to the same laundering procedures. It is proposed that the reason for the difference in values is that the cotton used during the knitting of the two samples could have differed in terms of a variety of factors, such as maturity and fineness of the fibres, which could have an effect on the extent of chemical damage during the laundering process.

From the fluidity test results it was expected that the cotton/polyester samples would appear weaker than the cotton/nylon samples, but this was not the case. It is therefore proposed that the most important cause of the difference in tensile strength between the washed and tumble-dried samples is the degradation of the synthetic yarns in the ground structure and not the cotton pile yarns or the second set of cotton warp yarns.

The significant decrease in the tensile strength of the cotton/nylon terry cloth after the 50 wash/tumble-dry cycles can be ascribed to the weakening of the nylon fibres when exposed to the severe friction action with concurrent high temperature during the tumble-drying process (while still in the wet and probably slightly swollen stage). The fact that the tensile strength of the cotton/polyester terry cloth samples remained almost unchanged after the 50 wash/tumble-dry cycles is a good indication of the excellent abrasion resistance and resilience of polyester, enabling it to withstand repeated and lengthy tumble-dry cycles.

\section{CONCLUSIONS AND RECOMMENDATIONS}

The durability of cotton warp knitted terry cloth with a nylon ground structure and cotton warp knitted terry cloth with a polyester ground structure were compared after exposure to industrial laundering procedures to determine how important it is that industrial launderers and consumers should be made aware of the presence of small quantities of synthetic fibres in the construction of a fabric. After 50 wash cycles there was a similar decrease in the tensile strengths of both the cotton/nylon and the cotton/polyester terry cloth samples. There was however a significantly greater decrease in the tensile strength of the cotton/nylon warp knitted terry cloth samples compared to the cotton/polyester samples after the cycles that included washing as well as tumble-drying.

It is therefore concluded that industrial washing procedures have little or no effect on the durability of the nylon and polyester ground structures of warp knitted towels, but that the tumble-drying process has a significantly greater degrading effect on the nylon content of the cotton/nylon terry cloth fabric.

It transpires from literature that the tumble-drying temperatures for synthetics should be kept low to average (Hatch, 1993:206; Kadolph \& Langford, 2002:102; Tortora, 1992:131). Although the temperature setting of the industrial tumble-dryer was set to $120^{\circ} \mathrm{C}$, temperatures varying between only $104^{\circ} \mathrm{C}$ and $110^{\circ} \mathrm{C}$ were measured. Even such temperatures were clearly too high for the fabrics containing nylon and, as a result, they adversely affected the nylon component of the cotton/nylon warp knitted terry cloth samples.

In the light of the results of the fluidity tests, the important role that the polyester yarns in the ground structure play in ensuring durability of warp knitted terry cloth is underscored. The fact that the cotton content of these samples showed chemical deterioration (which subsequently translates into deterioration in tensile strength) would lead to the expectation that the 
tensile strength of the samples would be lower than that of their cotton/nylon counterparts. In contradiction, the opposite was found. When the results of this study, namely that the tensile strength in the warp direction of the cotton/nylon terry cloth samples was lower than that of the cotton/polyester terry cloth samples after 50 wash cycles and significantly lower after 50 wash/tumble-dry cycles, and the results of the fluidity tests are taken into account, it is clear that the polyester component plays a significant role in maintaining the tensile strength of the samples during the laundering procedures.

This study also proves that in fabrics classified as mixtures, as is the case with warp knitted terry cloth with a synthetic ground structure, even a small percentage of the minority fibre can play a significant role in maintaining the durability or in the degradation of the structure. Because of the low weights of nylon and polyester filament yarns, the percentage weight of the total fibre content that they comprise when they are only used in the ground structure may seem negligible, but they form an integral part of the structure.

The results of this study underline how important it is that towel manufacturers as well as consumers (in this case including the hospitality industry) should take cognisance of the fact that industrial laundering procedures, and specifically tumble-drying, have a detrimental effect on cotton/nylon than on cotton/polyester warp knitted terry cloth towels. The fibre content of textile products plays a critical role in the durability and required care procedures of textile goods. The importance of indicating the correct fibre content on labels of textile goods, even if it is less than $5 \%$, is clearly indicated in this study.

It is strongly recommended that manufacturers of textile goods in South Africa should accurately indicate the fibre content of textile goods on labels. In this way industrial laundries and/or consumers can take note of the correct fibre content and adapt the care procedures accordingly.

\section{REFERENCES}

ANAND, SC \& SMITH, HM. 1994. Comparative performance of woven and warp knitted towelling fabrics. Kettenwirk-Praxis 28(3):62-68.

BARRIE, D. 1994. How hospital linen and laundry services are provided. Journal of Hospital Infection 27 (3):219-235.

CSIR MANUFACTURING AND MATERIALS TECHNOLOGY CENTRE FOR FIBRES, TEXTILES AND CLOTHING. 2004. Laboratory Test Report: SABS test method 115. Port Elizabeth, South Africa.

DEANS, J. 2001. The modeling of a domestic tumbler dryer. Applied Thermal Engineering 21(9):977-990.

FABRIC CARE RESEARCH ASSOCIATION. 1993.
Washing technology. SDML Consultancy \& Training (RSA).

GOVERNMENT GAZETTE. 2005. Notice in terms of the merchandise marks act, (Act No. 17 of 1941) Government Gazette no.27538. Pretoria. Government printers.

HATCH, KL. 1993. Textile science. New York. West Publishing Company.

HEGDE, RR, DAHIYA, A \& KAMATH, MG. 2004. NyIon fibers. Available on line. URL: http:// www.engr.utk.edu/mse/pages/Textiles/Nylon\%

20fibers.htm. Accessed 30 August 2004. [Article on the internet.]

INNOVATIVE TECHNOLOGY MAKES ITS MARK. 2004. Instruction sheet for Raschel warp-knitting machine: Wirkbau-Superpol 14123.

JAKOBI, G \& LÖHR, A. 1987. Detergent and textile washing: Principles and practice. New York. Cambridge.

JOSEPH, ML. 1988. Essentials of textiles. $4^{\text {th }}$ ed. Fort Worth, USA. Saunders College Publishing.

KADOLPH, SJ \& LANGFORD, AL. 2002. Textiles. $9^{\text {th }}$ ed. Upper Saddle River, New Jersey. Pearson Education.

MASON, RW. 1999. Decades later, polyester forges new image. Textile World 149(1):57-60.

McINTYRE, JE. 2000. Synthetic fibres: nylon, polyester, acrylic, polyolefin. Cambridge. Woodhead Publishing Ltd.

MERKEL, RS. 1991. Textile product serviceability. New York. Macmillan Publishing Company.

MILLER, E. 1992. Textiles: Properties and behaviour in clothing use. $4^{\text {th }}$ ed. London. Batsford Academic and Educational.

SLATER, K. 1991. Textile degradation. Textile Progress 21(1/2):1-158.

SOUTH AFRICAN NATIONAL STANDARDS 2007. Fibre content labelling of textiles and other textile products. Ed 2.1.10235. Pretoria.

SPENCER, DJ. 1983. Knitting technology. Oxford. Pergamon Press.

STEYN, HJH. 1994. Die invloed van wasmiddels en wastemperatuur op die groei en afsterwing van Escherichia Coli. PhD Thesis. University of the Free State.

TAYLOR, MA. 1990. Technology of textile properties: An introduction. $3^{\text {rd }}$ ed. London. Forbes Publications Ltd.

TORTORA, PG. 1992. Understanding textiles. $4^{\text {th }}$ ed. New York. Macmillan Publishing Co Ltd.

TROTMAN, ER. 1984. Dyeing and chemical technology of textile fibres. $6^{\text {th }}$ ed. London. Charles Griffin and Company Ltd.

WINGATE, IB \& MOHLER, JF. 1984. Textile fabrics and their selection. $8^{\text {th }}$ ed. Englewood Cliffs, New Jersey. Prentice-Hall.

WISKA. 2003. Towel. http://www.wiska.co.id/ e_towel.htm. Retrieved 19 July 2003.

WOOTEN, HL.1979. What's new in terry towel preparation? Textile Chemist and Colorist 11(6):136-138. 